\title{
State LGBT Rights Policy Outliers: Transsexual Birth Certificate Amendment Laws
}

\author{
Jami K. Taylor, Barry L. Tadlock, and Sarah Poggione
}

This paper explores an anomaly in gay, lesbian, bisexual and transgender (LGBT) rights policy, laws allowing transsexual individuals to amend their birth certificates. Unlike most other LGBT rights policies, these statutes are often found in Southern and other conservative states. In fact, these laws are found in half of the Southern states. The array of states with these laws does not conform to the traditional pattern of morality politics laws that is commonly associated with LGBT rights. Using a Cox non-proportional hazards model, we find that the adoption of these laws was influenced by vertical diffusion of the Centers for Disease Control's model vital records recommendations. States with more professionalized bureaucracies, like Virginia and Georgia, were more likely to implement these recommended best practices. However, as transgender rights became more closely associated with the gay rights advocacy movement, this issue likely resembles morality policy. The result being that liberal and conservative elites respond to these policies in predictable manners. Notably, the political opportunity structure in Southern states has not allowed the passage of this type of statute since the incorporation of transgender rights into the LGBT social movement during the mid-1990s.

The issue of civil rights for lesbians, gays, bisexuals and transgender (LGBT) persons currently falls under the domain of morality politics. Given the sharp clash over values, conservative states are unlikely to enact proLGBT rights measures while liberal states are more likely to do so. As such, states like Massachusetts and California are far more likely to pass relationship recognition measures like same-sex marriage or domestic partnership. Alternatively, it is no surprise that relatively conservative states, like those in the South, fail to enact many common pro-LGBT rights laws. As of 2011, no Southern state has a law that protects gay or transgender persons from discrimination in employment, housing or public accommodations. Similarly, no Southern state has a gender identity or sexual orientation inclusive hate crimes law. Furthermore, no Southern states have laws that allow for samesex marriage, civil union or domestic partnership. Contrary to this well documented trend, there exists a pro-LGBT rights policy that does not fit this pattern, laws allowing transsexual people to amend their birth certificates in the event of sex reassignment. While these transsexual birth certificate amendment laws are sometimes found in the usual suspect states, these

JAMI K. TAYLOR is Assistant Professor of the Department of Political Science and Public Administration at the University of Toledo, Toledo, Ohio. BARRY L. TADLOCK is Associate Professor of the Department of Political Science at Ohio University, Athens, Ohio. SARAH POGGIONE is Associate Professor of the Department of Political Science at Ohio University, Athens, Ohio. 
statutes also surprisingly exist in some conservative jurisdictions. This includes about half of the states in the South and in Utah. Since this pattern contradicts the morality politics explanation, we are left with a puzzle. Why have these more conservative and mostly Southern states adopted this particular pro-LGBT policy? This paper investigates and offers an explanation for this anomaly.

We use event history analysis to test a model of state policy adoption for laws allowing birth certificate amendment by transsexual individuals. This methodological approach allows us to consider both internal and external determinants of policy adoption. We find that the spread of these measures was affected by vertical policy learning over time via model vital records statutes offered by the Centers for Disease Control and Prevention (CDC), particularly in states with more professional state bureaucracies. Additionally, we find that despite a surprising disconnect between citizen ideology and the adoption of these technical statutes, political elites respond to these matters in ways similar to other policies related to LGBT rights. Our answer to the Southern puzzle demonstrates that some LGBT issues in some time periods are significantly influenced by other political processes and do not uniformly exhibit manifestations of morality politics.

\section{Transsexual Birth Certificate Amendment Laws}

Despite the removal of most de jure forms of discrimination and trends towards increasing equality between men and women, a person's sex remains an important consideration in some policy areas. Among other things, men and women are segregated in prisons; also, women are not required to register for Selective Service. In a more salient policy area, marriage in most states remains limited to heterosexual couples. Despite the relevance of sex in policy, it has no nationally recognized legal definition and the many medical markers that experts use to determine sex may lead to contradictory results (Greenberg 1999; 2005). Despite the existence of other sometimes contradictory biological and psychological markers of sex, individuals are commonly classified as male or female at birth according to their external genitalia (Bishop and Myricks 2004). This sex classification, along with the other facts of birth, is registered according to the vital records laws existing in the state where the baby is delivered. Individuals use the resulting birth certificate to gain access to public education and to obtain other forms of identification (e.g., driver's license, Social Security records, and passport).

Beyond the various biological markers of sex, such as the balance of hormones, internal/external organs, and genetic makeup, there exists gender identity, one's internal identification as male or female. When a person experiences some degree of gender dysphoria, that individual is sometimes 


(a)

referred to as transgender. Transgender is an informal term that comprises informally named gender dysphoric identities like crossdressers, gender queer people, and of special relevance to this research, transsexual individuals (Currah et al. 2006). This latter group comprises individuals with a "strong and persistent cross-gender identification" (American Psychiatric Association 1994).

The origins of transsexualism are thought to be either genetic (Green 2000; Henningsson et al. 2005) or related to prenatal exposure to abnormal levels of sex hormones (Kruijver et al. 2000; Zhou et al. 1995). This condition is not very responsive to psychotherapy (Cohen-Kettenis and Gooren 1999). For individuals with severe gender identity disorders, sex reassignment surgery is the most effective treatment available (Cohen-Kettenis and Gooren 1999). Upon completion of the appropriate medical treatment, 25 states statutorily allow transsexual individuals to amend their birth certificates. Of the other 25 states, Tennessee explicitly bans birth certificate amendment in the event of sex reassignment (Tennessee Statute 68-3-203). Three states appear to have an administrative process that determines the regulations for birth certificate amendment while New York has a two-tiered system that gives New York City authority to issue regulations independently of how they are issued elsewhere in the state. The remaining 20 states have a general statute allowing birth certificate amendment. While many of these 20 states amend birth certificates in the event of sex reassignment, the lack of direct statutory authority to amend the sex marker on birth certificates has sometimes led to judicial decisions that ignore such changes (Littleton v. Prange 1999; In re Estate of Gardiner 2002).

Given current marriage restrictions in most states and under the continued enforcement of the federal Defense of Marriage Act (DOMA), legal recognition as the acquired sex has important implications. In the 25 states that provide statutory guidance about sex reassignment, such individuals appear to be classified according to the amended birth certificate. As noted in the immigration case In re Jose Mauricio Lovo-Lara (2005), the federal government must apply DOMA with deference to these state policies. Where the explicit birth certificate amendment laws exist, a post-operative male-tofemale transsexual person with appropriate documentation would be legally viewed as a female and could thus marry a male. However, in the states that lack direct statutory guidance, the marriage rights of transsexual individuals are less clear and are open to more legal challenges. In some of these states, courts have not respected birth certificates that were changed under general amendment laws (Littleton v. Prange 1999; In re Estate of Gardiner 2002; Greenberg and Herald 2005). Where the courts have taken such stances, it appears that a post-operative male-to-female transsexual woman would be allowed to marry a genetic female. This would be true despite the trans- 
sexual woman holding a driver's license and U.S. passport with female sex designations, and being recognized as female by the Social Security Administration.

Despite the importance of these birth certificate laws, these statutes have received little attention in the political science and public administration literature. Most LGBT rights research has focused on hate crimes laws, non-discrimination statutes and constitutional amendments or laws banning same-sex marriage (e.g., Haider-Markel, 2001a). A consistent take away from this body of work is that conservative states are less likely to enact proLGBT rights laws than are liberal states. However, for birth certificate amendment laws, this relationship does not appear to hold. Figure 1 compares the ideological distribution of citizens in states having transsexual birth certificate amendment laws with those having sexual orientation inclusive employment discrimination laws. The states having gay inclusive nondiscrimination laws are more liberal on average than those that do not have such measures. This is consistent with the morality politics explanation. In contrast, there appears to be little relationship between ideology and the adoption of transsexual birth certificate amendment statutes. In the following section, we review the literature on policy diffusion in an attempt to identify other explanations.

\section{Policy Diffusion}

Different states quite often pass similar policies within a relatively short time period. Frequently, the adoption pattern when plotted against time displays an "S curve" with a period of rapid policy adoption that is bookended by periods of sparse adoption by the early innovators and laggards (Gray 1973). The process by which policies spread among the states is termed diffusion (Gray 1994). From the policy diffusion perspective, significant influences in innovation stem partly from sources external to the state. These external factors are experienced through social learning from the federal government (Allen et al. 2004; Welch and Thompson 1980) and via state and local governments (Berry and Berry 1990; Shipan and Volden 2006). Additionally, states learn from state, regional, and national policy networks (Gray 1994). State policymakers look to the practices in other states, typically following the lead of innovative states (Walker 1969). They might also consider the actions of other states in order to understand how policies fit into the ideological continuum (Gilardi 2010; Grossback et al. 2004). Frequently, policymakers emulate the policies of nearby states since these states are likely to exhibit similar demographic and ideological profiles. However, Boehmke $(2009,1136)$ cautions against "false evidence of policy emulation." He argues that what is actually occurring is policy convergence. 
Figure 1. Ideological Comparison:

States with Transsexual Birth Certificate Amendment Laws

vs. States with Gay Employment Nondiscrimination Laws

\section{Transsexual Birth Certificate Amendment Law}

Law

No Law

Sexual Orientation Inclusive Employment Nondiscrimination Law

Law

No Law

Berry et al. Citizen Ideology Measure

0

20

40

60

80

100

The importance of regional networks in policy diffusion may also be declining due to technological change, the development of professional organizations, and the growth of national policy networks (Gray 1994; Martin 2001).

The advocacy work of national policy networks sometimes leads to similar legislation in various states (Haider-Markel 2000, 2001b; Kirst et al. 1984). Groups that are a part of these national networks can be integral at several points in the policy diffusion process, particularly during the agenda setting and the information generation stages (Karch 2007). This is certainly true in the domain of LGBT rights policy. National organizations like the Human Rights Campaign (HRC) and the National Gay and Lesbian Task Force (NGLTF) assist their statewide counterparts in promoting LGBT rights initiatives. Furthermore, the Equality Federation, a coalition of statewide LGBT rights groups, promotes best practices and provides technical assistance to its members. Of course, groups that oppose LGBT rights, such as the National Organization for Marriage, the American Family Association, and the Family Research Council, are heavily involved in state politics directly or through affiliated organizations. In addition to the role played by national policy networks, previous studies also demonstrate the significance of agenda-setting factors such as court decisions and media attention (Oakley 2009). Thus, while Volden et al. (2008) argue that states might indepen- 
dently make similar policy choices, the documented activities of policy networks make it unlikely that states address LGBT rights in a vacuum.

Despite the likely existence of policy learning from forces external to the state in the LGBT rights realm, Mooney and Lee $(1995 ; 1999)$ find that internal factors are the decisive forces in morality politics. Scholars such as Gray (1994) have identified three broad classes of internal determinants (economic, political and social factors). However, research on LGBT rights policy demonstrates that political and social factors are key. For instance, Democratic control facilitates the adoption of gay rights legislation (HaiderMarkel 2001b; Herrick 2008). In general and despite the occasional incongruence between public opinion and state policy, liberal states are more likely to adopt gay rights measures than are conservative states (Lax and Phillips 2009).

The social factors of interest in the study of LGBT rights law include religion and state education levels. The percentage of Protestant Evangelicals within a state has a negative effect on the passage of pro-gay rights legislation (Barclay and Fisher 2003; Haider-Markel 1999, 2001a; HaiderMarkel and Meier 2003). In spite of this, religious organizations' utilization of their vast communications networks is not always realized (Djupe and Olson 2010), suggesting that the effect is not an inevitable one. Research has also shown that in states with higher percentages of college graduates there tends to be more tolerant attitudes towards minority groups. Thus, these states are less likely to adopt discriminatory policies such as bans on samesex marriage (Barclay and Fisher 2003; Haider-Markel and Meier 2003; McClosky and Brill 1983).

While political and social factors appear to be important in the spread of sexual orientation inclusive laws, it is important to note three significant limitations to this work that relate to our project. First, Barth and Parry (2009) remind us of the distinctiveness of each issue within the LGBT realm. Transsexual birth certificate amendment statutes might qualitatively differ from issues like same-sex marriage or hate crimes law. These differences might alter the scope of conflict. Second, while predictable differences between "blue states" and "red states" are often in evidence when it comes to the passage of statewide sexual orientation inclusive policies, there is a lack of systematic empirical analysis on transgender-related policy in the political science and public administration disciplines (Taylor 2007). With few exceptions (Colvin 2007; Nownes 2010) much of the field's work is rooted in critical or legal perspectives (e.g., Currah et al. 2006). As such, we do not fully understand how, when, and why these policies are adopted. Third, while we currently place all LGBT policies under the morality politics umbrella, the relatively recent inclusion of the " $\mathrm{T}$ " in LGBT raises questions about gender identity related policy in the years prior to its inclusion. 
In fact, the concerns of transsexual and other gender variant individuals have not always been so closely intertwined with those of the lesbian, gay, and bisexual communities. After World War II, many gay and lesbian individuals, particularly those from the middle and upper classes, redefined their identities. Rather than maintaining an identity rooted in gender-related nonconformity, gay people wanted to be viewed as part of the mainstream. The only significant difference with heterosexuals was the focus of their sexual attraction (Minter 2006; Wilchins 2004). As a result, gender variant gay and trans individuals were marginalized within or excluded from the nascent gay rights movement because many movement leaders perceived them as a threat to political progress (Minter 2006). This exclusion would exist from the 1970's through the early 1990's (Gallagher 1994; Wilchins 2004). It was not until 1996 that the executive director of the National Gay and Lesbian Task Force issued this statement: "The Task Force strongly supports civil rights protections and affordable health care for transgender [people]. We loathe discrimination and violence perpetrated against transgenders and stand in solidarity with transgender people in their struggle for visibility, inclusion, equality and justice" (National Gay and Lesbian Task Force 2011).

As noted in Table 1, since this explicit linkage of transgender rights with gay rights advocacy, the number of states adopting these transsexual birth certificate amendment laws has dropped precipitously. Of the 25 states with such laws, only three have been adopted since the National Gay and Lesbian Task Force's 1996 statement. None of the three later adopting states are in the South. The first Southern state to adopt a law was North Carolina in 1975; the last Southern state to adopt a law was Maryland in 1995. What explains the adoption of these policies across the nation? What explains the 20 -year burst of activity among the Southern states and the more recent lack of statute adoption in that region?

\section{Vertical Diffusion and Bureaucratic Professionalism}

If morality politics might not fully account for the historical development of these birth certificate amendment laws, then what remains to explain their passage, particularly within the South? In a broad sense, it could be the notion of "good government." Scholars and practitioners in the mid-twentieth century stressed the importance of good government, often discussed with respect to gains in productivity and/or efficiency (Martin 1992). Indeed, the National Center for Health Statistics was formed in 1960 with the purpose of "inter-governmental data sharing" and to foster the spread of standards and procedures (CDC 2011). This emphasis on efficiency and on the rational and technical components of legislation led the Centers for Disease 
Control and Prevention to issue model vital records statutes (1977 and 1992) that could be emulated by the states (CDC 1997). ${ }^{1}$ These policy recommendations included provisions for birth certificate amendment for individuals who had undergone medical treatment for transsexualism. We argue that these model records statutes recommended by the CDC were likely to produce vertical diffusion as states moved to adopt these health policy related best practices. However, states may not have been equally likely to respond to such non-compulsory vertical influences. Given the technical nature of birth certificate law, state administrators, particularly those serving in professionalized bureaucracies, might be more intimately familiar with the nature of the relevant policies. The street level bureaucrat (Lipsky 1980) experience gained through case work with transsexual individuals would alert them to gaps in existing policy. As such, their technical expertise and knowledge of new policy challenges could drive agenda setting (Kingdon 2003). We expect that those states with more professionalized bureaucracies are more likely to receive and incorporate the information provided by the CDC. Therefore, we expect that these states, responding to vertical diffusion processes, are more likely to adopt the recommended policies.

Hypothesis 1: States with higher levels of bureaucratic capacity are more likely to respond to guidance from the CDC's model vital records laws by adopting these statutes.

While birth certificate amendment rules are arcane technical concerns, we know that transgender rights have increasingly become a salient policy issue (Gallagher 1994; Taylor 2007). The adoption of gender identity inclusive nondiscrimination statutes in more than a dozen states since the $1990 \mathrm{~s}$ constitutes partial evidence of this fact. In a few jurisdictions, there are also transgender inclusive hate crimes laws or statutes that protect such individuals from bullying in schools. As such, we expect other cues, including citizen ideology, to affect legislators' consideration of these pro-transgender laws (Lax and Phillips 2009). In particular, we expect that states with liberal populations will be more likely to pass these laws, given the current association of transgender rights with the morality policy laden domain of gay rights. Additionally, not only should citizen ideology affect passage, but so too should elite ideology. Despite mixed evidence concerning the effect of elite ideology on various LGBT issues (Lax and Phillips 2009), we expect that liberal elite ideology will positively influence the passage of these laws.

Hypothesis 2: Those states with relatively higher percentages of liberal citizens are more likely to pass a birth certificate amendment law. 
Hypothesis 3: Those states with relatively higher percentages of liberal elites are more likely to pass a birth certificate amendment law.

\section{Data and Methods}

We model the likelihood of a state adopting a transsexual birth certificate amendment law in a particular year as a product of the motivation for efficient, rational policy, political forces, and a series of commonly used control variables. Given the dichotomous dependent variable, and pooled time series nature of our data (1962-2006), we utilize event history analysis to test our hypotheses. Because we argue that the effects of bureaucratic professionalism should differ across time, based on vertical diffusion through information provided by the CDC, we employ the Cox non-proportional hazards model in our analysis (see Box-Steffensmeier et al. 2003) with the exact partial likelihood method for resolving tied failures. ${ }^{2}$ This model allows us to relax the assumption that the hazard rates associated with particular independent variables remain constant over time. In other words, we can use this technique to examine how states' interest in pursuing efficient, rational policy influences state policy on transgender issues and how such influence responds to vertical diffusion over time.

The dependent variable is a binary indicator of whether a state adopted a statute explicitly allowing birth certificate amendment in the event of sex reassignment. Information on whether a state had one of these laws was obtained from the Human Rights Campaign's website. The research team, to the best of its ability, determined the year of adoption through statutory analysis via state legislative websites and Lexis-Nexis. Additionally, we contacted state archives and libraries and relied heavily on this information to clear up ambiguities in our research. ${ }^{3}$ The earliest adoption was in Illinois (1962), while the most recent statute was passed by Iowa (2006). ${ }^{4}$ Through 2006, 25 states had laws allowing for amendment. Table 1 provides a chronological order of adoption. Of the remaining 25 states, Washington, Nevada, and Maine (Title 22 \$2705) appear, based on information obtained from the Human Rights Campaign in 2006 (Taylor 2007), to give administrators latitude to promulgate regulations. Indeed, Nevada's birth certificate process is addressed in its administrative code rather than through statutes. In the case of New York, it has a two-tier system where New York City administers its own birth certificates through a separate code. Given the choice in these states to imbue bureaucratic agencies or localities with the authority to determine birth certificate amendment procedures, these states may no longer be at risk to adopt a birth certificate amendment laws, having settled the matter with an alternative to legislation. However, the choice to defer 
Table 1. Birth Certificate Adoptions by Year

\begin{tabular}{cccc}
\hline State & Year of Adoption & State & Year of Adoption \\
\hline IL & 1962 & GA & 1982 \\
HI & 1973 & CO & 1984 \\
NC & 1975 & MO & 1984 \\
NH & 1976 & NJ & 1984 \\
CA & 1977 & WI & 1985 \\
MI & 1978 & KY & 1990 \\
LA & 1979 & AL & 1992 \\
VA & 1979 & NE & 1994 \\
AR & 1981 & MD & 1995 \\
MA & 1981 & CT & 2001 \\
NM & 1981 & AZ & 2004 \\
OR & 1981 & IA & 2006 \\
UT & 1981 & & \\
\hline
\end{tabular}

such decisions to other governmental actors in no way limits the legislature from adopting such laws. Given the uncertainty about the continued existence of favorable administrative practices, the possibility for inconsistency in the application of bureaucratic discretion, and the possibility of legal challenges, interested parties may be unsatisfied with an administrative resolution and continue to advocate for a legislative one. In a very real sense, these states are still at risk since they have not adopted formal legislation. As a result, we include these four states in our analysis; however, our findings are robust to their exclusion. ${ }^{5}$

\section{Independent and Control Variables}

The independent variables in our analysis include two measures of state bureaucratic professionalism, state political forces, and a variety of control variables. To assess the professionalism of state bureaucracy and the resulting interest in rational and efficient policy, we measure state administrative performance using the 2008 Pew Center on the States' review of government performance. This measure of administrative performance captures differences in management capacity across a broad array of administrative agencies and actors in each of the states (see Burke and Wright 2002). Following Burke and Wright (2002) we converted the letter grades assigned by the Pew Center into numeric scores by utilizing indicators in the areas of finance, staffing, infrastructure and information management. The Pew Center ranks each of the 20 indicators as an area of weakness, average, or area of strength. We converted this to a numeric score by summing the following assigned 
values: 1 point for a weakness, 3 points for average and 5 points for an area of strength. The hypothetical range for our measure of bureaucratic performance and professionalization is 20 to 100 while the actual range was 30 to 94. The mean level of bureaucratic professionalization and performance was 60. While this measure of bureaucratic professionalism is static, it is highly correlated with the Pew Center's earlier but not directly comparable 1997 measure $(\mathrm{r}=.70)$. This high correlation suggests that although state administrative performance likely varies over time within states, the relative positions of states across time remain somewhat consistent.

However, we recognize the potential weaknesses of a static measure of bureaucratic professionalism and therefore include a dynamic measure of state bureaucratic professionalism, the number of state government health employees as a percentage of state population. This data was obtained from the U.S. Census Bureau. ${ }^{6}$ Not only is this measure dynamic, varying within states over time, it is also focused specifically on health related state employees, the people most likely to observe CDC guidelines and advocate for their inclusion in state policy. For example, this measure includes, but is not limited to, state workers employed in jobs related to public health administration, vital statistics, and public health education.

In order to assess the possibility of vertical diffusion, we include multiplicative interaction terms of our proxy measures of professionalized state bureaucracy with a lagged measure of federal influence via the CDC guidelines. The indicator for the CDC recommendations is coded 0 before any guidelines were issued, coded 1 from 1978-1992 after the Centers for Disease Control and Prevention issued the Model State Vital Statistics Act in 1977, and coded 2 for 1993-2006, after the CDC offered revised guidelines in 1992. Each of these recommended best practices contained provisions allowing for the amendment of birth certificates in the event of sex reassignment (1977 Section 21(e); 1992 Section 21 (d)).

Given the demonstrable importance of ideology in morality politics, we assess the role of political forces by using Berry et al.'s (1998) revised 19602008 citizen ideology series and their revised 1960-2008 ADA/COPE measure of state government ideology. ${ }^{7}$ While many studies of LGBT rights laws include measures of Democratic Party control of the state legislature and governor's mansion, the period of study in our research presents a problem. Currently, Democrats are more likely to support LGBT rights than are Republicans. However, the anti-civil rights and conservative cultural stances of Southern Democrats during the 1960's render problematic the direct measurement of partisan dominance. Instead, we rely on Berry et al.'s (1998) measure of state government ideology. This variable takes account of differences in party across states and it incorporates the legislature and governor. 
Based on studies of policy diffusion, we include several control variables. To account for the possibility of policy learning among states, we control for such horizontal diffusion by using the lagged percentage of states in the U.S. Census defined geographic region that have a transsexual birth certificate amendment law. To account for a state's general orientation toward policy innovation, we include Walker's (1969) measure of state policy innovation with the missing values for Hawaii and Alaska assigned at the mean. We control for possible regional influences by using a dichotomous indicator of Southern and non-Southern states. To control for the possibility that more professional legislatures are more likely to adopt new and diffusing policies, we include Squire's index $(1992 ; 2007)$ of state legislative professionalism.

Additionally, we control for three demographic factors that are common in studies of LGBT rights policies: education levels, the percentage of same-sex households in the state, and the percentage of Evangelical adherents in the state. With respect to education levels, our variable measures the percentage of residents who are age 25 or older with a bachelor's degree or higher. To construct this annual measure, we interpolated between statistics available in the 1962 and 2011 editions of Statistical Abstract of the United States. The percentage of same-sex households in a state is used as a proxy for gay interest group strength and is held constant at 2000 levels (Barclay and Fisher 2003). ${ }^{8}$ Our measure of Evangelical adherents was obtained from the Association of Religion Data Archives (ARDA). Their denomination classification scheme is based on the work of Steensland and his co-authors (2000). Following Erikson et al. (1993), we include members of the Church of Jesus Christ of Latter-Day Saints in our Evangelical measure, given their similar views on public policy matters. We use ARDA's1990 estimate of Evangelicals and hold this constant because of variation in data collection methodology. Particularly problematic is that the 2000 ARDA estimates do not include congregation data for historically African-American denominations (Association of Religion Data Archives 2010).

\section{Analysis}

Before we turn to the results of our analysis, we present in Table 2 (first two columns) the results of a Cox model that assumes proportional hazards. Note that only citizen ideology, state government ideology, and Walker's measure of state innovation have statistically significant coefficients. Based on this model, neither measure of state bureaucratic professionalism has a significant effect on the likelihood of state adoption - a result that runs counter to Hypothesis 1 . The results for citizen ideology also contradict Hypothesis 2; more liberal citizen ideology seems to reduce the likelihood of a state 


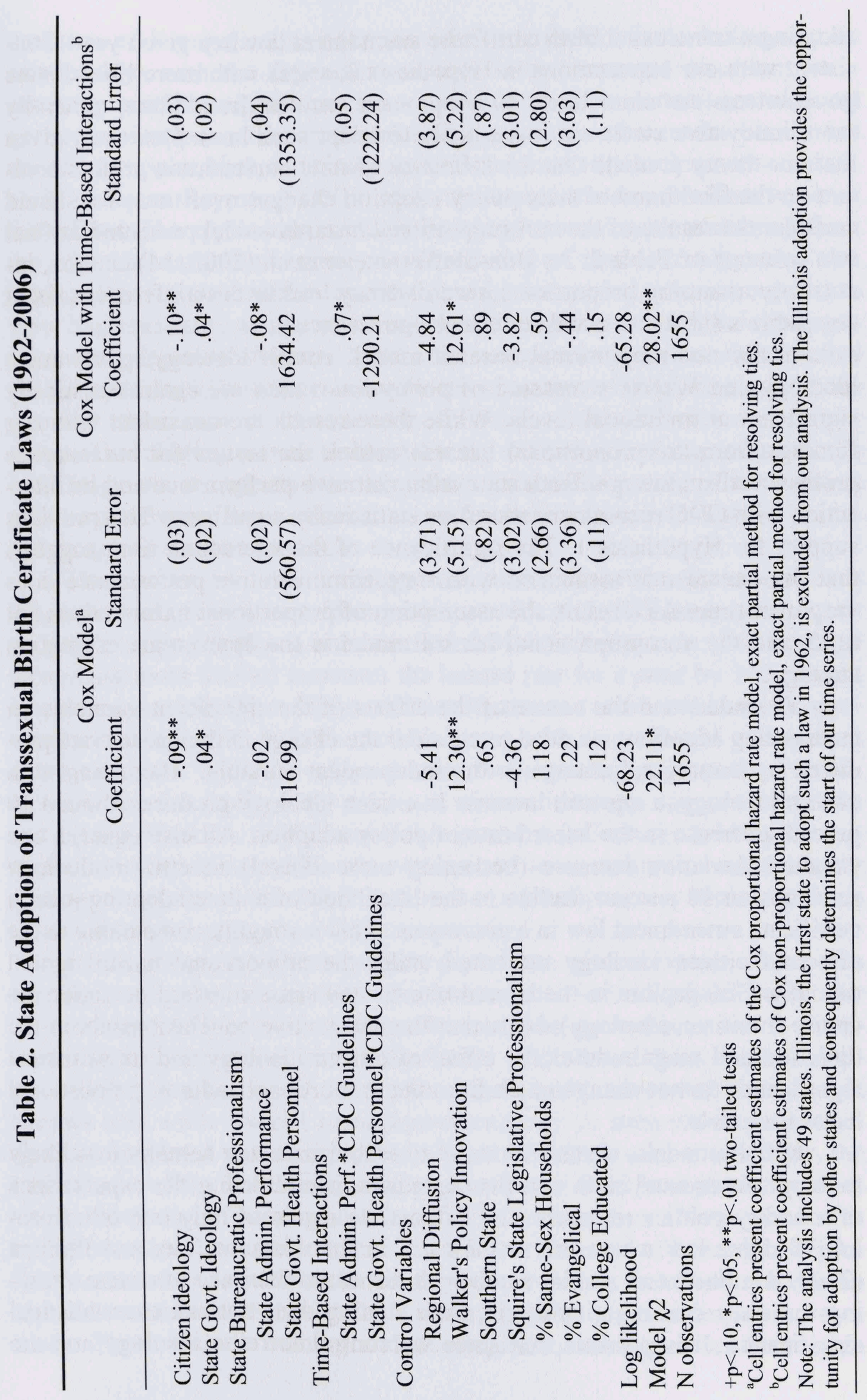


adopting a transsexual birth certificate amendment law in a given year. Consistent with our expectations in Hypothesis 3, states with more liberal state governments are more likely to adopt such statutes. In addition, generally more innovative states are more likely to adopt such laws. However, given that our theory predicts that the influence of state bureaucratic professionalism on the likelihood of state policy adoption changes over time, we should consider the results of the non-proportional hazards model presented in final two columns of Table 2. As Box-Steffensmeier et al. $(2003,34)$ caution, incorrectly assuming proportional hazards "may lead to false inferences about a variable's substantive and statistical significance."

In the non-proportional hazards model, citizen ideology, government ideology and Walker's measure of policy innovation are again statistically significant at traditional levels. While these results are consistent with our findings from the proportional hazards model, the results for bureaucratic professionalism are not. Both state administrative performance and its interaction with $\mathrm{CDC}$ recommendations are statistically significant. This provides support for Hypothesis 1 . The significance of the interaction term suggests that the hazard rate associated with state administrative performance does vary over time. As a result, the assumption of proportional hazards does not hold, and the non-proportional hazard model is the appropriate estimation strategy.

To understand the nature of the effects of the significant variables on state policy adoption, we need to consider the change in the hazard rate produced by a marginal change in the independent variable. ${ }^{9}$ Beginning with citizen ideology, a one unit increase in citizen ideology produces about a 10 percent decrease in the hazard rate of policy adoption. All else equal, a one standard deviation increase (becoming more liberal) in citizen ideology produces an 80 percent decline in the likelihood of a state adopting a birth certificate amendment law in a given year. This is roughly comparable to the effect of citizen ideology estimated under the proportional hazard model (about a $77 \%$ decline in the hazard rate for the same standard deviation increase in citizen ideology). Note that the substantive conclusions about the direction and magnitude of the effect of citizen ideology and its statistical significance do not change much from the proportional and non-proportional hazards models.

In both models, states with more liberal citizens are actually less likely to adopt transsexual birth certificate statutes, contradicting the expectations of morality politics research. The authors are aware of only one other proLGBT rights law where this is the case. In that instance, Lax and Phillips (2009) demonstrate a similar result with respect to the issue of a state allowing same-sex marriage. However, their finding does not achieve statistical significance. It is possible that since we control for elite ideology and the 
presence of Evangelical or Mormon adherents (both of which demonstrate relationships with the dependent variable in the expected direction), conservative publics might view sex reassignment as maintaining traditional gender stereotypes rather than undermining notions of a gender binary and therefore support birth certificate amendment laws. Some feminist scholars, such as Janice Raymond (1979), have criticized transsexual identity along these lines. The application of traditional gender stereotypes stemming from the 19th and early 20th century understanding of homosexuality may also explain this counterintuitive finding. During this period, it was common to view homosexuality as gender inversion--lesbians were masculine while gay men were feminine (Minter 2006). The connection between conservative opinion and birth certificate amendment after sex reassignment might tap into this older view of the intertwined nature of sexual desire and gender status. This finding serves to illustrate the difference among issues in the LGBT agenda. It suggests that the politics surrounding some of these issues may be determined by a different set of forces and factors than those prevalent in typical morality politics.

The results for elite ideology are consistent with our expectations (Hypothesis 3), which stem from previous work on LGBT issues and morality politics. Specifically, a one standard deviation increase in elite ideology (becoming more liberal) increases the hazard rate for a state by 162 percent in a given year, an effect that is identical to the one estimated in the proportional hazards model. In both models, states with more liberal government elites are more likely to adopt this particular transgender policy. Taken collectively, the findings for elite and citizen ideology support Lindaman and Haider-Markel's (2002) claim that position differences held by Democratic and Republican elites do not lead to issue evolution related party sorting among the public in all culture war related policies. Birth certificate amendment laws appear to follow in that vein.

In the non-proportional hazards model, the results for one of the two measures of state bureaucratic professionalism are consistent with our expectations in Hypothesis 1. State bureaucratic performance has a statistically significant impact on the likelihood of birth certificate policy adoption while the measure of state government health personnel does not. It appears that while overall management capacity in state executive branch agencies is related to state adoption of birth certificate amendment laws, the relative size of the health related state government workforce has little effect on the likelihood of passing such laws. ${ }^{10}$ Because the Pew Center measure is multidimensional, we believe that it is a better measure of bureaucratic professionalism than is state health employees per capita. In addition, it explicitly addresses items that relate to the concept of professionalism in bureaucracy. These include training and development, strategic workforce plan- 
ning, and managing employee performance (Pew Center 2008). As such, it is not surprising that this measure better explains which states might be more responsive to $\mathrm{CDC}$ guidance. Furthermore, the measure of state health employees includes workers who have no impact over matters related to vital records and therefore captures health-related state capacity well beyond the issue of birth certificate amendments.

Statistical significance of the interaction term for state administrative performance indicates that this particular measure of bureaucratic professionalism does not have a uniform hazard rate. In order to fully understand the impact of state bureaucratic performance, we graph the percentage change in the hazard rate of policy adoption produced by a marginal increase in each independent variable over time estimated under the non-proportional model. We also include an estimated change in hazard rate under the proportional model for comparison. We present these estimates in Figure 2.

\section{Figure 2. Percent Change in Estimated Hazard Rate for State Administrative Performance, Nonproportional and Proportional Hazard Rate Models}

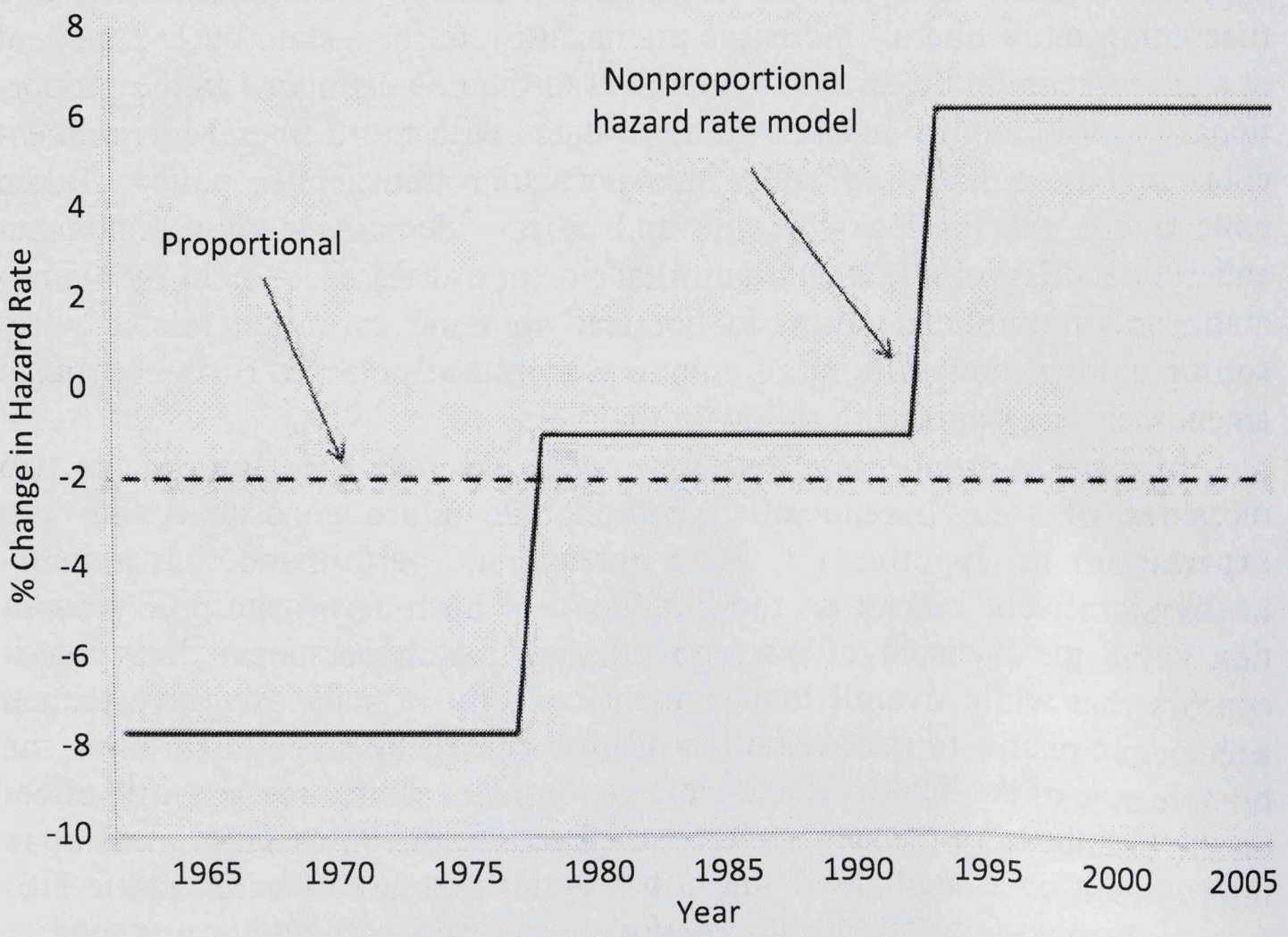


The solid line in Figure 2 represents the change in hazard rate due to a one unit increase in state administrative performance under the non-proportional hazard model. Note that in the earliest period, 1962-1977, before the $\mathrm{CDC}$ issued any relevant recommendations, a one unit increase in state administrative performance produces an 8 percent decline in the hazard rate of policy adoption. To put this variable in perspective, a standard deviation increase would produce a 64 percent decline in the hazard rate. This suggests that absent any advice from the $\mathrm{CDC}$, states with more professionalized bureaucracies are less likely to adopt such policies than are states with less professional bureaucracies. Perhaps this represents a reluctance to engage in ad hoc policymaking absent professional consensus. In the 1978 to 1992 period, after the CDC has issued its first recommendation for permitting birth certificate amendment after sex reassignment, the same one unit and in state administrative performance results in a 1 percent decline in the hazard rate. A one standard deviation increase during this period now only results in a 12 percent decline in the hazard rate. During this middle time period, differences in the hazard rates of states with more and less professional bureaucracies narrow. In the final period (1993 to 2006), beginning after the CDC reaffirmed its recommendation for birth certificate amendment laws, the hazard rate increased markedly in response to improved state administrative performance. During this period, a one unit increase in this measure of bureaucratic professionalism results in a 6 percent increase in the hazard rate. A one standard deviation increase would produce a 118 percent increase in the hazard rate, making states with professional bureaucracies far more likely than those with less professional ones to adopt this pro-transgender statute in any given year in the final time period.

For comparison, consider the dashed line in Figure 2, the estimated percentage change in the hazard rate under the proportional hazards assumption. Under the proportional hazards model, a one unit increase in state government performance always produces about a 2 percent decline in the hazard rate regardless of CDC recommendations. Even a one standard deviation increase in state government performance only yields a 23 percent decrease in the hazard rate. Not only are both the coefficients for state administrative performance and its interaction not statistically significant under the proportional hazards model, the estimated substantive impact of state administrative performance is quite small. This demonstrates how the conclusions regarding the impact of bureaucratic professionalism on state adoption of such laws differ significantly between the non-proportional and proportional hazards models. The non-proportional hazards model shows the process of vertical diffusion at work through the advice of the CDC and the attention of professional bureaucracies in a way that is not apparent in the proportional hazards model. 
Of the control variables, Walker's measure of policy innovation has a significant effect. In both the proportional and non-proportional hazards models, generally innovative states are more likely to modernize the vital records laws than are less innovative states. After accounting for vertical diffusion, policy innovation, state bureaucratic professionalism, and political forces (elite ideology and citizen ideology), regional diffusion and region (Southern state) do not significantly condition state policy choices in this area. After considering those same factors, state demographics (education levels, Evangelical adherence, and same-sex partnered households) offer no additional explanatory power. In addition, the professionalism of state legislative institutions is not significantly related to state adoption of birth certificate amendment laws. ${ }^{11}$

While the proportional hazards model suggests that vertical diffusion and bureaucratic professionalism provide an explanation for the adoption of transsexual birth certificate amendment laws, it is not clear whether this would explain the puzzle of the adoption of these laws in Southern states. While our results suggest that other political processes also influence this particular policy decision, to explain the Southern puzzle, we should also observe higher bureaucratic professionalism among the Southern states that adopted such policies compared to non-adopters in the South and in other regions. Table 3 provides a breakdown of the mean level of bureaucratic professionalism for states adopting and not adopting a transsexual birth certificate law in each of the four U.S. Census Bureau defined regions of the United States. ${ }^{12}$ Southern states that adopted these measures have a higher level of bureaucratic professionalism than those Southern states that failed to do so. ${ }^{13}$ Furthermore, of the four regions, Southern states adopting these measures have the highest mean level of bureaucratic professionalism. It is plausible that, particularly in the South, bureaucrats who were predisposed towards good governance (in this case, following the CDC's model vital records guidelines) created a political opportunity structure that allowed for

\section{Table 3. Mean Professionalism by U.S. Census Region and the Existence of a Birth Certificate Law}

\begin{tabular}{lcc}
\hline Census Region & No Birth Certificate Law & Birth Certificate Law \\
\hline South & $60.75(\mathrm{n}=8)$ & $65.00(\mathrm{n}=8)$ \\
Northeast & $52.80(\mathrm{n}=5)$ & $47.00(\mathrm{n}=4)$ \\
Midwest & $64.28(\mathrm{n}=7)$ & $64.40(\mathrm{n}=5)$ \\
West & $59.60(\mathrm{n}=5)$ & $59.00(\mathrm{n}=8)$ \\
Total Mean Professionalism & $59.92(\mathrm{n}=25)$ & $60.08(\mathrm{n}=25)$ \\
\hline
\end{tabular}


the passage of these statutes. This follows the point raised by Wald (2000, 17) when he noted that "the governmental structure offers places where minorities may overcome their numerical disadvantages to contest successfully for policy change."

\section{Conclusion}

This paper investigated an anomaly in LGBT rights law, states statutorily allowing for the amendment of birth certificates in the event of sex reassignment. Unlike other LGBT rights laws, these policies appear in a number of relatively conservative states, notably several in the South. We find that vertical diffusion of policy via recommendations from the CDC affected the adoption of these laws. In 1977 and again in 1992, the CDC promoted these policies as best practices in their model vital records legislation. In states with more professionalized bureaucracies, administrators may have shepherded these guidelines before legislators as part of the agenda setting process. The policies appear to have been treated as low salience technical matters. However, as transgender identity has become more politically salient since the mid-1990s, we have seen fewer states adopting these laws. Hawaii's 1993 same-sex marriage case, Baehr v. Lewin, might have given policymakers reason to consider the implications of allowing a person to legally change sex. Additionally, as the transgender movement has become increasingly attached to gay rights advocacy, transsexual birth certificate amendment proposals might be less likely to be viewed as purely technical concerns. After all, our model demonstrates that political elites respond to this issue in predictable patterns. Conservative elites find themselves against these policies while liberal elites are more likely to offer support. As such, it is likely that the factors affecting the adoption of transsexual birth certificate policies and other transgender rights issues might increasingly resemble those of other LGBT rights policy.

While we are confident in our findings, it is important to note several limitations in our work. As mentioned in our discussion of the independent variables, one of our measures of bureaucratic professionalization varies across states but is constant over time. Unfortunately, the discipline lacks consistent multi-dimensional measures of this concept over time and as such, we might miss how states have professionalized their bureaucracies over the decades. Additionally, given the age of some of these statutes and their technical nature, there remains the possibility that we have flaws associated with our dependent variable. However, we took several precautions. This included checking our list of state laws with sources such as the Human Rights Campaign. Our team also corresponded with officials in many of the states with birth certificate amendment laws. Another possible issue is that our 
measure of interest groups active on this issue may be incomplete. For example, medical centers or universities, engaged in treatment for these gender identity conditions, may have pushed state legislators to pass these policies. Unfortunately, we are not aware of any comprehensive listing of such centers over time. However, we include two variables (Evangelical and same-sex partner households) that often serve as proxy measures of interest group strength in this policy domain.

Our research has important implications for the study of lesbian and gay rights. For example, Button and his colleagues $(2000,272)$ note that the "legal successes of gays in the early 1970s were also achieved because of the lack of organized resistance." So it seems reasonable to suggest that the political opportunity structure that was present in many Southern states during 1975-1995 was such that the rights of some transgendered individualsin the case of birth certificate amendment laws - could be advanced without engendering debilitating opposition. Furthermore, a sufficient number of political elites in these states believed that attention to "best practices" was a wise course of action. Or at the very least, the issue of birth certificate amendment was not one on which very many state legislators were willing to get in the way of their state's bureaucracy following the model provided by the CDC. Indeed, we demonstrate that gains in LGBT rights can occur by means of public policy that is mediated through bureaucratic structures. Echoing Wald (2000), this finding highlights another possible way in which gay and transgender rights activists can successfully advance their cause.

However, our findings also raise a difficult question: has the association of transgender rights with the gay rights movement, at least over the past 20 years, damaged the prospects for legal recognition of a transsexual person's sex? While the association of transgender persons with the gay rights movements was not done solely for prospective policy gains, the increased salience of transgender identities may have expanded the scope of conflict. Given the public's conflation of LGBT identities and the various communities' common problems associated with the stereotyping of gender, it is plausible that there have been negative ramifications that have received insufficient scholarly attention. In a related point, if same-sex marriage ever becomes a nationwide policy in the United States, will the policy relevance of the sex marked on a transsexual person's birth certificate decline as a matter of public importance? Another point of inquiry concerns the interesting relationship between citizen ideology and these transsexual birth certificate amendment laws. Might these statutes be associated with the protection of gender norms and a binary gender system? While these questions are beyond the scope of our research, our work has contributed to a fuller understanding of LGBT politics and suggested a number of new and interesting questions for future research to explore. It also shows how that even in 


\section{Southern states, the blockage of LGBT rights policy advances is not a fore- gone conclusion.}

\section{NOTES}

${ }^{1}$ The Bureau of the Census issued earlier versions of a Model Vital Records Act in 1907 and 1942. In 1959, the Department of Health Education and Welfare issued new recommendations. The 1977 revision by the CDC was a major change from its predecessors and called for increased centralization of records keeping and reporting. There was an emphasis placed on efficiency and effectiveness (Centers for Disease Control and Prevention 1997). While we have not investigated whether the 1959 version of the Model Vital Records Act contained provisions for amendment in the event of sex reassignment, we rate such a recommendation as unlikely given that the first publicized case of medical sex reassignment of an American was Christine Jorgensen in the early 1950s. It is plausible that sex reassignment might have made an appearance in the initial National Center for Health Statistics' Model State Vital Statistics Regulations (issued in 1973). While we have not explored that possibility, we note that regulations do not require an act of the legislature.

${ }^{2}$ We estimate the model using the more common Breslow method for resolving tied failures (not reported). The results are strikingly similar and not particularly sensitive to the choice of method. Given the greater accuracy of approximating the partial likelihood with the exact partial likelihood method (Box-Steffensmeier and Jones 2004), we present only these results here.

${ }^{3}$ The authors thank Susan Brace of the University of Toledo for her many hours of dedicated assistance in data collection. We also express thanks to Ryan Combs of the University of Manchester for his constructive comments.

${ }^{4}$ The early adoption of a transsexual birth certificate amendment law in Illinois was confirmed in two separate self-reports. The statute was also referenced in a 1974 case about criminalized cross-dressing that was before the Illinois Supreme Court in 1978 (City of Chicago v. Wallace Wilson et al. (75 Ill. 2d 525; 389 N.E.2d 522; 1978 Ill. LEXIS 402; 27 Ill. Dec. 458)). As a result, we begin our analysis in 1962. We assume, as Berry and Berry (1990) do, that other states were then 'at risk' for adopting such a law now that one state had done so. As the first state to adopt such a law, Illinois is effectively eliminated from the analysis. However, given that the second adoption didn't occur until a decade later, we also estimated a model beginning in 1972 (not reported). The results from the analysis beginning in 1972 are remarkably consistent and substantively identical to the results beginning with 1962. As a result, we report only the results of analysis beginning in 1962 .

${ }^{5} \mathrm{We}$ estimated a model that excludes these four states, assuming that the existence of their administrative procedures eliminated their risk for adoption. The results of this supplemental analysis (not reported) are strikingly similar to the findings we report. As a result, we report only the findings from the analysis that includes these four states.

${ }^{6}$ U.S. Census Bureau records held state health full-time equivalent (FTE) employee data for the years 1962, 1967, 1972, 1977, 1980-1995, and 1997-2006. The measure is computed by dividing state health employee FTEs by state population. Missing data was interpolated. The data base ("Annual Survey of State and Local Government Employment and Census of Governments") is an internal file of the U.S. Census Bureau (the 
Employment and Benefit Statistics Branch) and is shared with outside data users upon request.

${ }^{7}$ Available from Richard Fording's website at the University of Kentucky, http:// www.uky.edu/ rford/stateideology.html.

${ }^{8}$ This statistic was not collected prior to 1990 .

${ }^{9}$ The percentage change in the hazard rate associated with a one unit increase in $\mathrm{X}$ is $\left(\mathrm{e}^{\mathrm{b}}-1\right) * 100$.

${ }^{10}$ To address the possibility that state health personnel per capita was too narrow of a measure of state bureaucratic professionalism, we also estimated the model using U.S. Census Bureau statistics on the total number of state employees relative to the state population (not reported). Our results were similar to those reported for state government health personnel. In both cases the employee based measure of state bureaucratic professionalism and its interaction with the CDC recommendations were not statistically significant.

${ }^{11}$ To account for the possibility that more professional legislatures might also respond to vertical diffusion through the CDC's communication of best practices, we estimated the model including the interaction of Squire's index of state legislative professionalism and the CDC recommendations. Neither of the coefficients for state legislative professionalism or its interaction were significant at traditional levels. Given the technical nature of this policy area, professionalism of state bureaucratic institutions rather than legislative institutions seems necessary for states to modernize their vital records laws.

${ }^{12}$ The mean level of professionalism is derived from our conversion of the Pew Center's state ratings. For further information, please refer to the discussion of this measure in the data and methods section.

${ }^{13} \mathrm{~A}$ t-test to assess whether this difference in means is of statistical significance is not needed. There is no chance that this difference is the result of sampling. We have information on all states.

\section{REFERENCES}

Allen, Mahalley, Carrie Pettus, and Donald P. Haider-Markel. 2004. Making the National Local: Specifying the Conditions for National Government Influence on State Policy Making. State Politics \& Policy Quarterly 4(3):313-344.

American Psychiatric Association. 1994. Diagnostic and Statistical Manual of Mental Disorders: DSMIV. Washington, DC: American Psychiatric Association.

Association of Religion Data Archives. 2010. Sources of Religious Congregations and Membership Data. http://www.thearda.com/mapsReports/RCMS_Notes.asp (accessed March 11, 2011.)

Barclay, Scott, and Shauna Fisher. 2003. The States and the Differing Impetus for Divergent Paths on Same-Sex Marriage, 1990-2001. Policy Studies Journal 31(3):331352.

Barth, Jay, and Janine Parry. 2009. Political culture, Public Opinion, and Policy (Non) Diffusion: The Case of Gay- and Lesbian-Related Issues in Arkansas. Social Science Quarterly 90(2):309-325.

Berry, Frances Stokes, and William D. Berry. 1990. State Lottery Adoptions as Policy Innovations: An Event History Analysis. American Political Science Review 84(2): 
Berry, William D., Evan J. Ringquist, Richard C. Fording, and Russell L. Hanson. 1998. Measuring Citizen and Government Ideology in the American States, 1960-1993. American Journal of Political Science 42(1):327-348.

Bishop, E.P., and Noel Myricks. 2004. Sex Reassignment Surgery: When is a He a She for the Purpose of Marriage in the United States? American Journal of Family Law 18(1):30-35.

Boehmke, Frederick J. 2009. Policy Emulation or Policy Convergence? Potential Ambiguities in the Dyadic Event History Approach to State Policy Emulation. Journal of Politics 71(3):1125-1140.

Box-Steffensmeier, Janet M., Dan Reiter, and Christopher Zorn. 2003. Nonproportional Hazards and Event History Analysis in International Relations. Journal of Conflict Resolution 47:33-53.

Box-Steffensmeier, Janet M., and Bradford S. Jones. 2004. Event History Modeling: A Guide for Social Scientists. New York: Cambridge University Press.

Burke, Brendan, and Deil Wright. 2002. Reassessing and Reconsidering Reinvention in the American States: Exploring Administrative Performance. State and Local Government Review 34(1):7-19.

Button, James W., Barbara A. Rienzo, and Kenneth D. Wald. 2000. The Politics of Gay Rights at the Local and State Level. Pp. 269-289 in The Politics of Gay Rights, eds. Craig A. Rimmerman, Kenneth D. Wald, and Clyde Wilcox. Chicago: University of Chicago Press.

Centers for Disease Control and Prevention. 1977. 1977 Revision of the Model State Vital Statistics Act and Model State Vital Statistics Regulations. http://www.cdc.gov/ nchs/data/misc/mvsact77acc.pdf (accessed March 20, 2011).

Centers for Disease Control and Prevention. 1992. 1992 Revision of the Model State Vital Statistics Act and Model State Vital Statistics Regulations. http://www.cdc.gov/ nchs/data/misc/mvsact92b.pdf (accessed March 21, 2011).

Centers for Disease Control and Prevention. 1997. U.S. Vital Statistics System. http:// www.cdc.gov/nchs/data/misc/usvss.pdf (accessed March 21, 2011).

Centers for Disease Control and Prevention. 2011. Celebrating 50 Years. http://www. cdc.gov/nchs/about/50th_anniversary.htm (accessed January 1, 2012).

Cohen-Kettenis, P.T., and Louis Gooren. 1999. Transsexualism: A Review of Etiology, Diagnosis and Treatment. Journal of Psychosomatic Research 46(4):315-333.

Colvin, Roddrick. 2007. The Rise of Transgender-Inclusive Laws: How Well Are Municipalities Implementing Supportive Nondiscrimination Public Employment Policies? Review of Public Personnel Administration 27(4):336-360.

Currah, Paisley, Richard Juang, and Shannon Price Minter. 2006. Introduction. Pp. xiiixxiv in Transgender Rights, eds. Paisley Currah, Richard Juang, and Shannon Price Minter. Minneapolis: University of Minnesota Press.

Djupe, Paul A., and Laura R. Olson. 2010. Diffusion of Environmental Concerns in Congregations across U.S. States. State Politics \& Policy Quarterly 10(3):270-301.

Erikson, Robert S., Gerald C. Wright, and John P. McIver. 1993. Statehouse Democracy: Public Opinion and Policy in the American States. Cambridge: Cambridge University Press.

Gallagher, John. 1994. For Transsexuals, 1994 is 1969. Transgendered Activists are a Minority Fighting to be Heard Within the Gay and Lesbian Community. In Witness to Revolution: The Advocate Reports on Gay and Lesbian Politics, 1967-1999, ed. Chris Bull. Los Angeles: Alyson Books.

Gilardi, Fabrizio. 2010. Who Learns from What in Policy Diffusion Processes? American Journal of Political Science 54(3):650-666. 
Gray, Virginia. 1973. Innovation in the States: A Diffusion Study. American Political Science Review 67(4):1174-1185.

Gray, Virginia. 1994. Competition, Emulation, and Policy Innovation. Pp. 230-248 in Perspectives on American Politics, eds. Lawrence C. Dodd and Calvin Jillson. Washington, DC: CQ Press.

Green, Richard. 2000. Family Co-occurrence of 'Gender Dysphoria': Ten Sibling or Parent-child Pairs. Archives of Sexual Behavior 29(5):499-507.

Greenberg, Julie. 1999. Defining Male and Female: Intersexuality and the Collision between Law and Biology. Arizona Law Review 41:265-278.

Greenberg, Julie. 2005. When is a Same-sex Marriage Legal? Full Faith and Credit and Sex Determination. Creighton Law Review 38(2):289-. Retrieved December 7, 2006 from LexisNexis Academic database.

Greenberg, Julie, and Marybeth Herald. 2005. You Can't Take It With You: Constitutional Consequences of Interstate Gender-identity Rulings. Washington Law Review 80(4):819-885. Retrieved March 1, 2006 from LexisNexis Academic database.

Grossback, Lawrence J., Sean Nicholson-Crotty, and David A. M. Peterson. 2004. Ideology and Learning in Policy Diffusion. American Politics Research 32(5):521-545.

Haider-Markel, Donald P. 1999. Morality Policy and Individual-Level Political Behavior: The Case of Legislative Voting on Lesbian and Gay Issues. Policy Studies Journal 27(4):735-749.

Haider-Markel, Donald P. 2000. Lesbian and Gay Politics in the States: Interest Groups, Electoral Politics, and Public Policy. Pp. 290-346 in The Politics of Gay Rights, eds. Craig Rimmerman, Kenneth D. Wald, and Clyde Wilcox. Chicago: University of Chicago Press.

Haider-Markel, Donald P. 2001a. Policy Diffusion as a Geographical Expansion of the Scope of Political Conflict: Same Sex Marriage Bans in the 1990s. State Politics and Policy Quarterly 1(1):5-25.

Haider-Markel, Donald P. 2001b. Shopping for Favorable Venues in the States: Institutional Influences on Legislative Outcomes of Same-Sex Marriage Bills. American Review of Politics 22:27-53.

Haider-Markel, Donald P., and Kenneth J. Meier. 2003. Legislative Victory, Electoral Uncertainty: Explaining Outcomes in the Battles over Lesbian and Gay Civil Rights. Review of Policy Research 20(4):671-690.

Henningsson, Susanne, Lars Westberg, Staffan Nilsson, Bengt Lundström, Lisa Ekselius, Owe Bodlund, Eva Lindström, Monika Hellstrand, Roland Rosmond, Elias Eriksson, and Mikael Landén. 2005. Sex Steroid Related Genes and Male-to-Female Transsexualism. Psychoneuroendocrinology 30(7):657-664.

Herrick, Rebekah. 2008. The Responsiveness of State Legislatures and their Agenda Concerning Gay, Lesbian, Bisexual, and Transgender Interests. Social Science Journal 45(4):659-672.

In re Estate of Gardiner, 42P.3d 120 (Kan. 2002).

In re Jose Mauricio Lovo-Lara, 23 I\&N Dec. 746 (BIA 2005). http://www.usdoj.gov/ eoir/vll/intdec/vol23/3512\%20.pdf (accessed December 14, 2005).

Karch, Andrew. 2007. Democratic Laboratories: Policy Diffusion among the American States. Ann Arbor: University of Michigan Press.

Kingdon, John W. 2003. Agendas, Alternatives, and Public Policies, 2nd ed. New York: Addison Wesley Publishers.

Kirst, Michael W., Gail Meister, and Stephen R. Rowley. 1984. Policy Issue Networks: Their Influence on State Policymaking. Stanford, CA: Stanford University. 
Kruijver, Frank, Jiang-Ning Zhou, Chris W. Pool, Michel A. Hofman, Louis J.G. Gooren, and Dick F. Swaab. 2000. Male to Female Transsexuals Have Female Neuron Numbers in a Limbic Nucleus. Journal of Clinical Endocrinology Metabolism 85(2):818-827.

Lax, Jeffery R., and Justin H. Phillips. 2009. Gay Rights in the States: Public Opinion and Policy Responsiveness. American Political Science Review 103(3):367-386.

Lindaman, Kara, and Donald P. Haider-Markel. 2002. Issue Evolution, Political Parties, and the Culture Wars. Political Research Quarterly 55(1):91-110.

Lipsky, Michael. 1980. Street-level Bureaucracy: Dilemmas of the Individual in Public Service. New York: Russell Sage Foundation.

Littleton v. Prange, 9 S.W.3d 233 (Tex. App 1999).

Martin, D.W. 1992. The Management Classics \& Productivity. Pp. 47-62 in Public Productivity Handbook, ed. Marc Holzer. Marcel Dekker: New York.

Martin, Isaac. 2001. Dawn of the Living Wage: The Diffusion of a Redistributive Municipal Policy. Urban Affairs Review 36(4):470-496.

McClosky, Herbert, and Alida Brill. 1983. Dimensions of Tolerance: What Americans Believe About Civil Liberties. New York: Russell Sage Foundation.

Minter, Shannon Price. 2006. Do Transsexuals Dream of Gay Rights? Pp. 141-170 in Transgender Rights, eds. Paisley Currah, Richard Juang, and Shannon Price Minter. Minneapolis: University of Minnesota Press.

Mooney, Christopher Z., and Mei-Hsien Lee. 1995. Legislating Morality in the American States: The Case of Pre-Roe Abortion Regulation Reform. American Journal of Political Science 39(3):599-627.

Mooney, Christopher Z., and Mei-Hsien Lee. 1999. Morality Policy Reinvention: State Death Penalties. Annals of the American Academy of Political and Social Science 566:80-92.

National Gay and Lesbian Task Force. 2011. Task Force History. http://www.thetaskforce. org/about_us/history (accessed 13 March 2011).

Nownes, Anthony. 2010. Density Dependent Dynamics in the Population of Transgender Interest Groups in the United States 1964-2005. Social Science Quarterly 91(3): 689-703.

Oakley, M.R. 2009. Agenda Setting and State Policy Diffusion: The Effects of Media Attention, State Court Decisions, and Policy Learning on Fetal Killing Policy. Social Science Quarterly 90(1):164-178.

Pew Center on the States. 2008. Grading the States 2008. http://www.pewcenteronthestates.org/gpp report card.aspx (accessed March 11, 2011).

Raymond, Janice. 1979. The Transsexual Empire: the Making of the She-Male. London: Women's Press.

Shipan, Charles, and Craig Volden. 2006. Bottom-Up Federalism: The Diffusion of Antismoking Policies from U.S. Cities to States. American Journal of Political Science 50(4):825-843.

Squire, Peverill. 1992. Legislative Professionalization and Membership Diversity in State Legislatures. Legislative Studies Quarterly 17(1):69-79.

Squire, Peverill. 2007. Measuring Legislative Professionalism: The Squire Index Revisited. State Politics \& Policy Quarterly 7(2):211-227.

Steensland, Brian, Jerry Z. Park, Mark D. Regnerus, Lynn D. Robinson, W. Bradford Wilcox, and Robert D. Woodberry. 2000. The Measure of American Religion: Toward Improving the State of the Art. Social Forces 79(1):291-318.

Taylor, Jami K. 2007. Transgender Identities and Public Policy in the United States: The Relevance for Public Administration. Administration Society 39(7):833-56. 
U.S. Census Bureau. 1962, 1967, 1972, 1977, 1980-1995, 1997-2006. Annual Survey of State and Local Government Employment and Census of Governments.

Volden, Craig, Michael Ting, and Daniel Carpenter. 2008. A Formal Model of Learning and Policy Diffusion. American Political Science Review 103(3):319-332.

Wald, Kenneth D. 2000. The Context of Gay Rights. Pp. 1-30 in The Politics of Gay Rights, eds. Craig A. Rimmerman, Kenneth D. Wald, and Clyde Wilcox. Chicago: University of Chicago Press.

Walker, Jack L. 1969. The Diffusion of Innovations among the American States. American Political Science Review 63(September):880-899.

Welch, Susan, and Kay Thompson. 1980. The Impact of Federal Incentives on State Policy Innovation. American Journal of Political Science 24(4):715-29.

Wilchins, Riki Anne. 2004. Queer Theory Gender Theory: An Instant Primer. Los Angeles: Alyson Books.

Zhou, Jiang-Ning, Michel A. Hofman, Louis J.G. Gooren, and Dick F. Swaab. 1995. A Sex Difference in the Human Brain and its Relation to Transsexuality. Nature 378(6552):68-70. 